Ethical Issues in Nursing and Midwifery Practice 
Also by Win Tadd and published by Macmillan

Chadwick, R and Tadd, W (1992) Ethics and Nursing Practice: A Case Study Approach 


\section{Ethical Issues in \\ Nursing and Midwifery \\ Practice}

Perspectives from Europe

Edited by

Win Tadd 


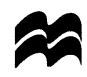

(C) Selection, editorial matter, Chapters 1 and 2, Win Tadd: 1998

(C) Other chapters in order: Astrid Norberg; Christine Chilton; June Smail and Rosie Tope; Helen Crafter and Cathy Rowan; Gosia Brykczynska; Ruth Northway; Kevin Gournay; Jan Reed; Kevin Kendrick; Verena Tschudin: 1998

(C) Foreword, Jane Salvage: 1998

All rights reserved. No reproduction, copy or transmission of this publication may be made without written permission.

No paragraph of this publication may be reproduced, copied or transmitted save with written permission or in accordance with the provisions of the Copyright, Designs and Patents Act 1988, or under the terms of any licence permitting limited copying issued by the Copyright Licensing Agency, 90 Tottenham Court Road, London W1P 9HE.

Any person who does any unauthorised act in relation to this publication may be liable to criminal prosecution and civil claims for damages.

The authors have asserted their right to be identified as the authors of this work in accordance with the Copyright, Designs and Patents Act 1988.

First published 1998 by

MACMILLAN PRESS LTD

Houndmills, Basingstoke, Hampshire RG21 6XS

and London

Companies and representatives

throughout the world

ISBN 978-0-333-71005-0 ISBN 978-1-349-14569-0 (eBook)
DOI 10.1007/978-1-349-14569-0

A catalogue record for this book is available from the British Library.

This book is printed on paper suitable for recycling and made from fully managed and sustained forest sources.

$\begin{array}{llllllllll}10 & 9 & 8 & 7 & 6 & 5 & 4 & 3 & 2 & 1\end{array}$

$\begin{array}{llllllllll}07 & 06 & 05 & 04 & 03 & 02 & 01 & 00 & 99 & 98\end{array}$

Editing and origination by

Aardvark Editorial, Mendham, Suffolk 
For Vic, Beccy and Andrew, my inspiration 


\section{Contents}

Foreword by Jane Salvage ix

Acknowledgements $\quad \mathbf{x}$

About the Contributors $\quad$ xi-xiv

1 Setting the scene 1 Win Tadd

2 Ethics in nursing $\quad 10$ Win Tadd

3 Moral reasoning in nursing: a view from Sweden Astrid Norberg

4 Nurses as health educators: the ethical issues 58 Christine Chilton

5 Community nursing: the ethical issues Rosie Tope and June Smail

6 Ethical issues in maternity care Helen Crafter and Cathy Rowan

7 Children, rights and nursing concerns Gosia Brykczynska

8 Ethical issues in integrating people with a mental handicap Ruth Northway

9 Ethical issues in mental health nursing Kevin Gournay

10 Ethical issues in the care of older people: difference, distinction and division Jan Reed

11 Ethical issues in critical care nursing Kevin David Kendrick 
viii Ethical Issues in Nursing and Midwifery Practice

12 Nursing ethics at the end of life

233

Verena Tschudin

Appendix: Extract from UKCC (1994) The Midwives'

Code of Practice

255

Index

256 


\section{Foreword}

I must admit I find the idea of ethics daunting and I am sure I am not the only one. It sounds such a dry, philosophical topic, providing scholars, priests and hermits with ample opportunity for learned speculation but bearing little relationship to the real world - particularly the messy, chaotic world of health care, which to its practitioners seems more real than most. Win Tadd and the contributors she has brought together in this book clearly disagree, and perhaps they share my view that just as politics is too important to be left to politicians and medicine too important to be left to doctors, so ethics is too important to be left to ethicists.

The recent growth in health professionals' interest in ethics has been striking, and has gradually widened to include nurses and others at all levels and in all areas of practice, the target audience for this book. Far from being consigned to a dusty, unwanted corner of the curriculum, ethical issues are increasingly prominent in everyday discussions about health care. The reasons are many and varied, but undoubtedly include the changing role and greater autonomy of nurses, who can no longer hide behind others' authority but are, as their regulatory body points out, individually accountable to the public for maintaining safe standards of care. At the same time, rising demands and inadequate health care resources often force practitioners and managers into making priority choices which they find difficult or even unacceptable.

The ethical issues are unavoidable - part of the fabric of human life. In health care they arise at policy level, with governments deciding which services, professions or research should receive most funding, or devolving those tricky rationing decisions to local level. One topical example is assisted conception: should this be provided by the National Health Service 
or should couples go private? Is it acceptable that availability of the state-funded service should depend on your postcode?

Even more pressing for the practitioner are the ethical issues which constantly arise in their daily work. At every turn they are required to make snap decisions about what to do for whom and how to do it. When staffing levels are low and clients' needs seem endless, how can they choose between competing, sometimes conflicting, demands? Who gets my attention first, the woman screaming in the corner or the one next to her in a wet bed? What do I say when the patient has not been given information about his diagnosis but the family has? These are real dilemmas which the practitioner often feels obliged to solve (or sidestep) in isolation, at the risk of being chided or punished for making the 'wrong' choice.

Any book which aims to stimulate debate on ethics in nursing is therefore to be welcomed. This one has a particularly innovative emphasis on the transcultural dimension. By taking a European perspective, with authors, case studies and examples from a wide range of countries, it enables us to flush out our taken-for-granted views and examine them in the light of others' experiences. It reminds us of the diversity of ethical views within our own multicultural, multi-ethnic societies: no homogeneous societies now exist, if indeed they ever did.

Comfortingly, though, there may be as much that unites us as divides us. As Tadd points out, 'transcultural ethics relies on a moral sense which originates from our shared humanity and shared human experiences... these elements of humanity all arise from basic fears, beliefs and values which are common across all cultures'. I found this to be true in my last job at the World Health Organization, where as Regional Adviser for Nursing and Midwifery in Europe, I worked with nurses from, and visited them in, many countries - from France and Spain in the west to Russia and Kazakstan in the east, all under the WHO umbrella of 'Europe'.

I observed a multitude of customs, assumptions, nuances, behaviours and attitudes, yet all of us were indeed united by shared humanity and shared experiences - and we also shared a passionate belief in the potential of nursing to cross the divides 
of gender, race, age, sexuality and so on, to join hands in empathy to alleviate suffering and help each other through hard times. This book provides stimulating, thoughtful and wellinformed debate to help us find our way through the moral mazes and thereby enrich our own, our colleagues' and our patients' lives.

Jane Salvage, RGN, BA, MSc HonLld

Editor-in-Chief, Nursing Times 


\section{Acknowledgements}

I owe a debt of gratitude to many people without whose help and support this book would not have been possible. I would first like to thank the contributors who, by their punctuality and diligence, made my task all the easier. Thank you.

Second, I shall be forever grateful to the numerous nurses in the UK and Europe who have shared their thoughts and experiences with me during my many years of teaching. The pleasure has been mine and I am quite certain that I have learnt a lot from them.

Particular thanks go to Richenda Milton-Thompson at Macmillan for her advice, understanding and endless patience in the preparation of this volume and to an anonymous reviewer for a helpful and encouraging critique.

To Marianne Arndt of the University of Stirling and Humboldt University in Germany, thank you for your patient reading of the manuscript and your constructive comments which were enormously helpful.

Finally, I would like to thank members of my family. My parents for their influence and example; my husband Vic, for his patient reading, helpful comments and culinary skills; and my children, Rebecca and Andrew, for just being themselves.

\section{Publisher's acknowledgements}

The editor and publishers wish to thank Academic Press: California, for their kind permission to reprint with minor editing, copyright material on pages 23-32 in this volume, from Tadd, W. (1997) 'Nurses' ethics', in Chadwick, R. (ed. in chief), Encyclopaedia of Applied Ethics. 


\section{About the Contributors}

Gosia Brykczynska BA, BSc, RN, RSCN, Cert Ed, RNT, Dip $\mathrm{PH}$, is Lecturer in Philosophy and Ethics at the RCN Institute, London. As a humanities graduate, she specialized in Soviet and East European studies. After working with leprosy patients for the US Public Health Service, she obtained a degree in Nursing Studies from Columbia University in New York City. She is currently undertaking doctoral studies in Philosophy at Heythrop College, London University.

Christine Chilton MA (ed.) BSc, Dip Soc Res, RGN, is a freelance writer now living in France. After graduating in biochemistry and pharmacology at the University of Sydney, she worked in the Australian pharmaceutical industry before qualifying as a Registered Nurse in Oxford. She also has a postgraduate diploma in social research and a master's degree in health education. Her professional interests include social pharmacology and empowerment through support networks. She is a member of the Editorial Advisory Board of the Journal of Substance Misuse.

Helen Crafter MSc, RGN, RM, RMT, is Senior Lecturer/Practitioner in Midwifery at Thames Valley University, London. She has clinical links at Queen Charlotte's and Chelsea Hospitals and in the community in west London. She qualified as a midwife teacher at the University of Surrey/Royal College of Midwives, London. In 1991 she completed an MSc in Health Education at King's College, London and is the author of Health Promotion in Midwifery published in 1997.

Kevin Gournay MPhil, PhD, C.Psychol, AFBPsS, RN, is Professor of Mental Health Nursing at the Institute of Psychiatry in London. He is responsible for the London Thorn Nurse Initiative and his clinical work involves him with patients suffering from post-traumatic stress disorder and schizophrenia. He has been a member of many advisory bodies including the 
current Mental Health Initiative and the Research Advisory Group for the High Security Commissioning Body. He has studied services in Europe, the USA and Australia. He is author of numerous journal articles, book chapters, and books.

Kevin Kendrick MSc, BA(Hons), Dip Soc Admin, Cert Ethics \& Theol, Cert Ed, FETC, RGN, EN(G), OTN, is Lecturer in Nursing and Ethics, School of Healthcare Studies, University of Leeds and is a member of the Royal College of Nursing's Ethics Committee. He is currently engaged in research critically exploring the moral dimensions of 'Living Wills' for Age Concern (UK) and is Network Editor for the international journal, Health Care in Later Life. He has published widely on the subject of nursing ethics.

Astrid Norberg RN, BA, MA, PhD, is Professor and Head of the Department of Advanced Nursing, Umeå University, Umeå, Sweden. Her research interests mainly concern ethics in nursing care and communication with people with severe dementia. She is a member of the scientific council of the Swedish National Board of Health and Welfare. In 1989 she received the Sofiahemmet prize and the Swedish King's medal, 8th degree (Serafimer), for her contribution to the development of nursing research in Sweden.

Ruth Northway $\mathrm{MSc}$ (Econ), RNMH, $\mathrm{ENB}(805)$, CertEd(FE), is Lecturer in Nursing Studies at the University of Wales College of Medicine, Cardiff. Prior to entering nurse education she worked as a Clinical Nurse Specialist for people with learning difficulties. She is currently studying for a doctoral degree and her research focuses on discrimination and people with learning difficulties. Both this research and previous studies have included a European dimension.

Jan Reed PhD, RN, is Professor in the Faculty of Health, Social Work and Education at the University of Northumbria, Newcastle. She qualified as a nurse in 1982, after completing à nursing degree at Newcastle Polytechnic, and in 1983 she was appointed as a research nurse in a care of the elderly unit in Newcastle. Her PhD, completed in 1989, explored how the 
expectations of older people shaped nurses' assessments of them. Her current research focuses on the care of older people, and she is founding editor of the journal, Health Care in Later Life.

Cathy Rowan MA, RM, Adv Dip M, RGN PGCEA, is Senior Lecturer in Midwifery at Thames Valley University, near Slough. She has clinical links at the Royal Berkshire Hospital in Reading and in the community. She is also a Supervisor of Midwives. She worked as a midwife in Africa and India, returning to the UK in 1986. Her MA studies were in medical ethics and her practice interests include issues surrounding pre-natal screening and diagnosis and birth.

June Smail BA(Hons), RGN, RM, DN, CertEd, is Senior Nurse for Primary Care with Gwent Health Authority. Her role involves advising and supporting practice nurses in Gwent on professional, clinical and educational issues, as well as commissioning for primary care and promoting teamwork and multidisciplinary learning in the community. She has many years' experience in community and practice nursing and in developing, and teaching on, Welsh National Board courses. She is an elected member of the UKCC.

Win Tadd PhD, BEd(Hons), RGN, RM, DN (Lond), RCNT, RNT, CertEd (FE), ONC, is an independent Consultant in Health Care Ethics and Education and lectures in the UK and Europe. Her doctoral thesis explored moral agency and the nurse's role and her many publications include Ethics and Nursing Practice of which she is co-author. She is an External Post-Doctoral Research Fellow at the Centre for Applied Ethics, University of Wales, Cardiff and with a research scholarship from the UKCC, is currently exploring how nurses use and interpret the Code of Professional Conduct in their practice. She is also a member of a European Union research team examining the relevance of virtue ethics to patients with chronic illness.

Rosie Tope PhD, MEd, RCNT, Cert Ed(FE), DN(Lond), is an independent Consultant in Interdisciplinary Learning and an 
External Fellow of the University of Glamorgan. She has a wide experience of teaching nurses as well as other health and social care professions. Her doctoral thesis examined the feasibility of interprofessional learning to enhance collaboration in patient care. She has facilitated a number of interprofessional workshops in the UK and Europe, is a member of various international organizations associated with health care and is author of a number of health service publications.

Verena Tschudin MA, BSc(Hons), RGN, RM, Dip Couns, is Senior Lecturer at the University of East London. She was born in Switzerland but did her nurse training in London after which she worked for many years in oncology in both the UK and Israel. In recent years, with two degrees in ethics, this has become her main area of concern. She has published widely in the fields of counselling and ethics and is editor of the international journal Nursing Ethics. 